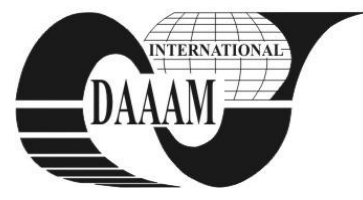

Annals of DAAAM for 2011 \& Proceedings of the 22nd International DAAAM Symposium, Volume 22, No. 1, ISSN 1726-9679 ISBN 978-3-901509-83-4, Editor B. Katalinic, Published by DAAAM International, Vienna, Austria, EU, 2011 Make Harmony between Technology and Nature, and Your Mind will Fly Free as a Bird

\title{
ANALYSES OF TESTING STAND FOR RADIAL HYDRAULIC FORGING MACHINE
}

\author{
MASEK, B[ohuslav]; HRONEK, P[avel] \& STADLER, C[tibor]
}

\begin{abstract}
A radial hydraulic forging machine with four forging units was developed in the Research Centre of Forming Technology FORTECH. A prototype of one of four units was manufactured for a stand to test machine control systems. Stress distribution and deformations within the testing stand were checked by FEM analyses and strain gauge measurements. Advancement in forging machine design was recommended from both viewpoints
\end{abstract}

Key words: forging machine, hydraulic units, testing stand, FEM, strain gauge measurement

\section{INTRODUCTION}

The aim of this paper is an analysis of a hydraulic radial forging machine. In the first part of the research a hydraulic unit and an unconventional machine frame were developed for a radial forging machine. The frame designed consists of four hydraulic units and plates made of ultra high strength steel. On each side of the machine there are two layers of plates and each layer consists of four plates (Fig.1). The plates are connected to the hydraulic units using preloaded bolts. The transfer of forging forces is ensured by circular keys which go through both layers of plates into the hydraulic units. To support the plates, brace struts are placed between the hydraulic units.

In the second part of the research, one hydraulic unit was manufactured. Basic tests were carried out in the testing stand to test the control system of the hydraulic unit. Simulations of the test frame were performed using FEM analyses and strain gauge measurements were made in order to establish recommendations for the machine frame design.(Hronek, 2010)

\section{PROBLEM DESCRIPTION}

First, one hydraulic unit was built to test its properties and behaviour in order to tune the drive control. The unit and the swage were placed in a simple two-column frame (Fig. 2).

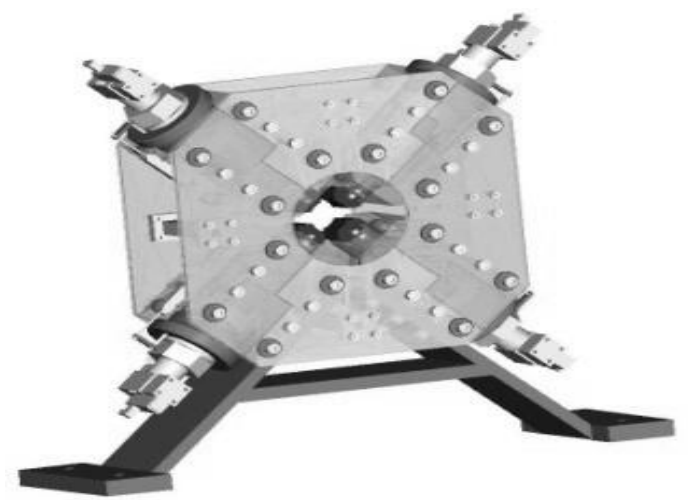

Fig. 1. Radial hydraulic forging machine

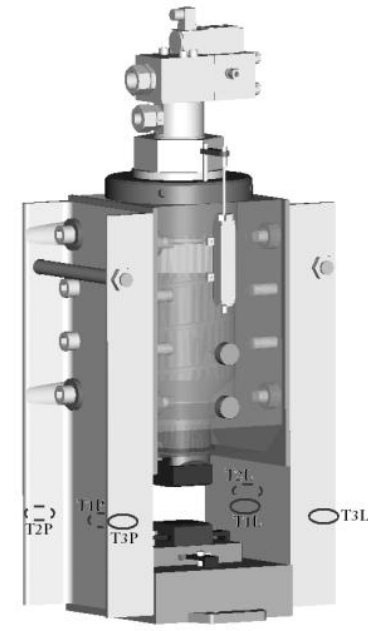

Fig. 2. Hydraulic unit testing stand

Considering that this is a machine with highly flexible stroke control, it is necessary to obtain exact feedback from the system for the precise positioning of the moving component, in this case the hydraulic cylinder on which the swage is placed. The drive control system is composed of two regulating loops. The internal loop regulates the position of the slide valve on the driving valve. Based on the difference between the required and actual position of the slide valve (the regulation deviation of the internal loop), the position of a magnetic valve is controlled by a proportional regulator.

The external loop, on the basis of the difference between the required and actual position of the swage, respectively the hydraulic cylinder (the regulation deviation of the external loop), regulates the required position of the slide valve of the control valve. A program in MATLAB was written for the trajectory of the required movement. Fig. 3 shows the required and actual trajectory of movement. In the first phase the swage moves to the required position, followed by holding in that position. Then the forging process is simulated with repeated strokes around the required position with a subsequent stop in the middle position. This data demonstrates the forging frequency, which in this case was $5 \mathrm{~Hz}$ (Fig.3).

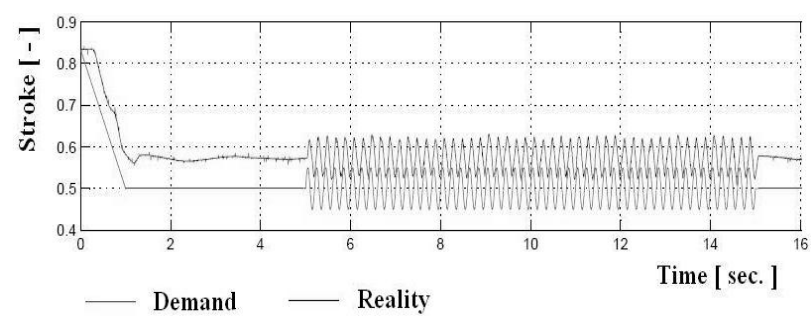

Fig. 3. Position of the swage over time 


\subsection{Test forging}

To verify the behaviour of the hydraulic unit with a resistance corresponding to hot forging in industry, test forging was carried out on a model semi-product; a flat, lead bar measuring $45 \times 32 \mathrm{~mm}$ was forged which was prepared by casting in a cylindrical mould. The test forging gradually reduced the thickness of the bar from $30 \mathrm{~mm}$ to $25 \mathrm{~mm}$ and then $15 \mathrm{~mm}$. During forging there are clearly distinct chopped off tips of the sinewave, which indicates that the increased strain also increased the deviation from the ideal position (Fig.5). It can be seen in detail that, in both the loaded and unloaded state in these dynamic conditions, the complete sinewave cannot be achieved. The reasons for this lie in the material of the unit, real resistance, inertia, deformation properties of the semi-product, the properties of the regulator and a partial role is also played by the amount of hydraulic fluid supplied by the pump.

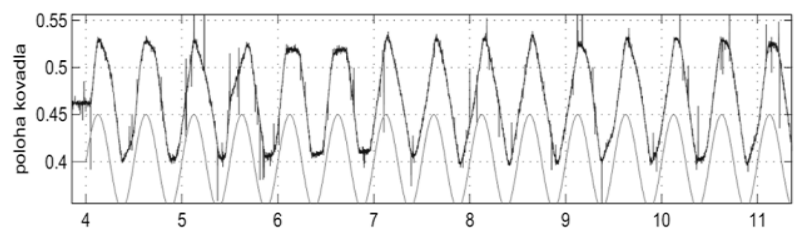

Fig. 4. Graph plotting the position of the swage over time when unloaded

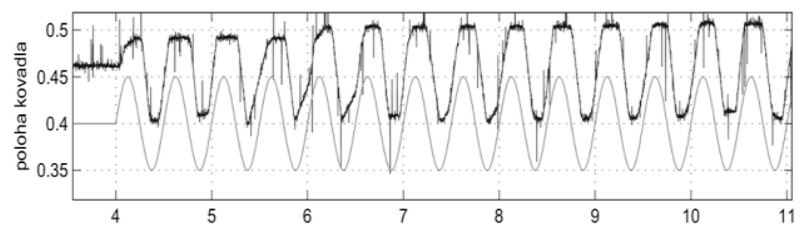

Fig. 5. Graph plotting the position of the swage over time when loaded

\subsection{FEM analysis}

The analysis was carried out using a 3D model of the frame. The model consists of two bodies. The first element is the hydraulic unit and the second is the weld of the two U-profiles and the lower crossbeam of the frame. Boundary conditions were set as follows:

- Model was fixed in places for bolts on the lower crossbeam

- Lower and upper crossbeam (element of hydraulic unit) were loaded by forming force $\mathrm{F}=500 \mathrm{kN}$

- Loading force was set eccentrically in the same way as in strain gauge measurement

(Ansys user manual)
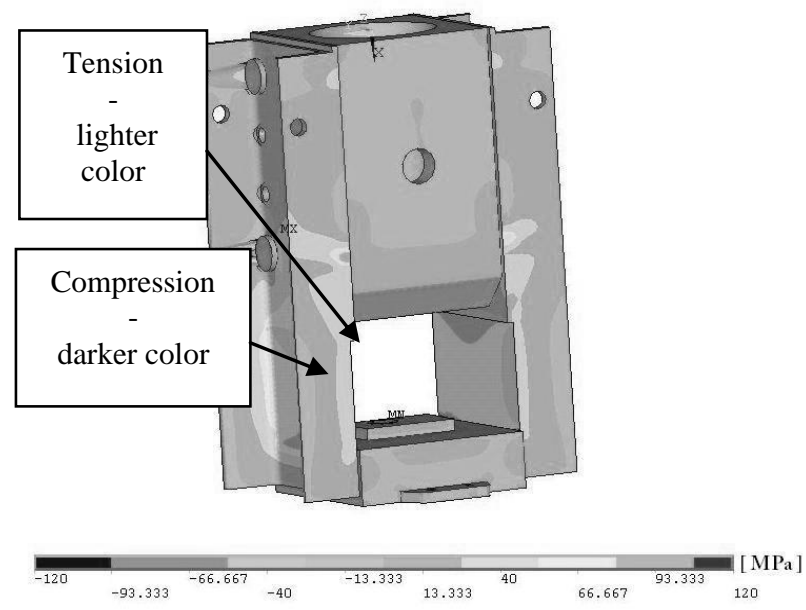

Fig. 6. Stress distribution in vertical axis

\subsection{Strain gauge measurement}

Measurement was carried out on the real model of the hydraulic unit for the radial forging machine. Positions for strain gauges were judged from the results of FEM analyses. Selected places were in the midway of the U-profile, between the lower crossbeam and the element of hydraulic unit, respectively in the middle of the U-profile and at the end of the shorter sides at the same height (Fig. 2 and Fig.7).

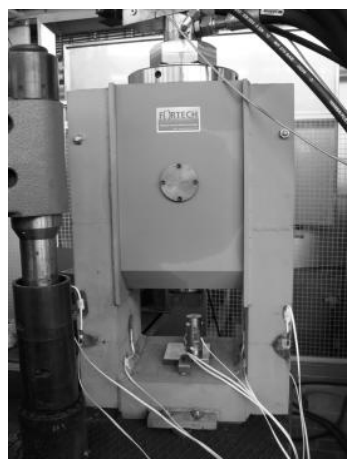

Fig. 7. Real model of hydraulic unit with strain gauges and eccentrically placed dynamometer

(Klement, 2004)

\subsection{Measurement evaluation}

Comparison of both analyses with the same eccentric load, which is the closest to the real load of the frame, proved sufficient correspondence. The results could be taken as relevant in both analyses.

\section{CONCLUSION}

A hydraulic unit was manufactured and tested in a testing stand for optimizing the construction of a forging machine for special uses. The results of the tests of the control system showed disagreement between the required and real course of the working stroke. This was solved by changing the PI regulator constants. Combined analysis of the strain stress states using FEM and strain gauge measurements proved sufficient stiffness of the testing frame even under eccentric loading. The results provide a basis for the successful application of the element into the overall concept of the machine.

\section{ACKNOWLEDGEMENTS}

This paper includes results created within the project 1M06032 Research Centre of Forming Technology. The project is carried out within the framework of the Research Centres (1M) programme and subsidised from specific resources of the Czech state budget for research and development.

\section{REFERENCES}

ASM International Committee: ASM Handbook - Forming and Forging, ISBN 0-87170-007-7, USA 1998

Klement, J., Plánička, F., Vlk, M.: Modelová podobnost, elektrická odporová tenzometrie Pilsen, University of West Bohemia, 2004

Masek, B.; Hronek, P. \& Stadler, C. (2010): FEM Analyses of Connections for Several Structures of a Hydraulic Radial Forging Machine, Annals of DAAAM for 2010 \& Proceedings of the 21st International DAAAM Symposium, 20-23rd October 2010, Zadar, Croatia, ISSN 1726-9679, ISBN 978-3-901509-73-5, Katalinic, B. (Ed.), pp. 08850886, Published by DAAAM International Vienna, Vienna

***ANSYS Users Manual, Release 10.0 documentation for Ansys

***Service documentation HBM, Strain gauges - strain gauge measurement, http://www.hbm.cz/ 